\title{
Role of autophagy in apoptosis induction by methylene chloride extracts of Mori cortex in NCI-H460 human lung carcinoma cells
}

\author{
SHIN-HYUNG PARK ${ }^{1 *}$, GYOO YONG CHI $^{1 *}$, HYUN SUP EOM $^{1}$, GI-YOUNG KIM $^{2}$, JIN WON HYUN ${ }^{3}$, \\ WUN-JAE KIM ${ }^{4}$, SU-JAE LEE ${ }^{5}$, YOUNG HYUN YOO ${ }^{6}$ and YUNG HYUN CHOI ${ }^{7,8}$ \\ ${ }^{1}$ Department of Pathology, College of Oriental Medicine and Research Institute of Oriental Medicine, \\ Dongeui University, Busan 614-052; ${ }^{2}$ Laboratory of Immunobiology, Department of Marine Life Sciences, \\ ${ }^{3}$ School of Medicine and Applied Radiological Science Research Institute, Jeju National University, Jeju 690-756; \\ ${ }^{4}$ Department of Urology, Chungbuk National University College of Medicine, Cheongju 361-763; ${ }^{5}$ Department of Chemistry \\ and Research Institute for Natural Sciences, Hanyang University, Seoul 133-791; ${ }^{6}$ Department of Anatomy and \\ Cell Biology, Dong-A University College of Medicine and Mitochondria Hub Regulation Center, Busan 602-714; \\ ${ }^{7}$ Department of Biochemistry, College of Oriental Medicine and Research Institute of Oriental Medicine, \\ Dongeui University, Busan 614-052; ${ }^{8}$ Department of Biomaterial Control (BK21 program), Graduate School and \\ Blue-Bio Industry Regional Innovation Center, Dongeui University, Busan 614-714, Republic of Korea
}

Received November 17, 2011; Accepted January 30, 2012

DOI: $10.3892 /$ ijo.2012.1386

\begin{abstract}
The root of Mori cortex has traditionally been used in Korea for the treatment of cutaneous inflammation, pulmonary asthma, and congestion for thousands of years. The present study was designed to validate the anticancer effects of methylene chloride extracts of the M. cortex root (MEMC) in NCI-H460 human lung carcinoma cells. Exposure to MEMC was found to result in growth inhibition by the induction of caspase-dependent apoptosis in NCI-H460 cells, which correlated with upregulated expression of death receptor (DR)4, DR5 and FasL, downregulation of anti-apoptotic Bcl-2 and Bcl-xL expression, cleavage of Bid, and loss of mitochondrial membrane potential. In addition, autophagosomes, a characteristic finding of autophagy, and markers of autophagy, conversion of microtubule-associated protein light chain-3 (LC3)-I to LC3-II and increased beclin-1 accumulation, were observed in MEMC-treated NCI-H460 cells. Inhibition of autophagy by 3-methyladenine or LC3B small interfering (siRNA) resulted in enhanced apoptotic cell death, suggesting that MEMC-induced autophagy functions as a suppressor of apoptosis. MEMC-induced autophagy was also
\end{abstract}

Correspondence to: Dr Young Hyun Yoo, Department of Anatomy and Cell Biology, Dong-A University College of Medicine, 3-1 Dongdaesin-Dong, Seo-Gu, Busan 602-714, Republic of Korea E-mail: yhyoo@dau.ac.kr

Dr Yung Hyun Choi, Department of Biochemistry, Dongeui University College of Oriental Medicine, Busan 614-052, Republic of Korea

E-mail: choiyh@deu.ac.kr

${ }^{*}$ Contributed equally

Key words: Mori cortex, autophagy, apoptosis, reactive oxygen species blocked by $\mathrm{N}$-acetyl-cysteine (NAC) and catalase, indicating that $\mathrm{H}_{2} \mathrm{O}_{2}$ can regulate autophagy. Our data demonstrate that MEMC triggers both ROS-mediated autophagy and caspasedependent apoptosis, and that autophagy plays a protective role against apoptotic cell death.

\section{Introduction}

Non-small cell lung cancer (NSCLC), accounting for $85 \%$ of all lung cancer, is the leading cause of cancer-related mortality worldwide. NSCLC causes over 1.2 million deaths each year, and the 5-year survival rate is only $15 \%(1,2)$. Despite the development of various therapies that target certain molecular pathways and significant advances in NSCLC tumor biology over the past year, current chemotherapies are considered to have reached a therapeutic plateau; therefore, more effective strategies for treatment of NSCLC are required $(3,4)$.

Apoptosis is a well-known type of programmed cell death (PCD) initiated from a death receptor- or mitochondrial-mediated signal. The death receptor-mediated pathway activates caspase- 8 by the formation of the death-induced signaling complex (DISC). Activated caspase- 8 then cleaves Bid to a truncated Bid (tBid), which connects the death-receptor pathway with the mitochondrial pathway through translocation from the cytosol to the mitochondria $(5,6)$. The mitochondrial pathway is initiated by the loss of mitochondrial membrane potential (MMP, $\Delta \psi \mathrm{m}$ ) and release of cytochrome $c$, leading to the activation of caspase- 9 and $-3(7,8)$. Autophagy is a well-conserved process characterized by the formation of autophagosomes, which fuse with lysosomes, finally resulting in lysosomal degradation of cytoplasmic constituents $(9,10)$. During this process, beclin-1 and the microtubule-associated protein light chain-3 (LC3) represent the major regulators. To date, a number of research studies have been conducted on the interplay between apoptosis and autophagy in response to 
various death stimuli. Autophagy has commonly been known to inhibit apoptosis and promote cell survival by the elimination of damaged cells prior to the induction of apoptosis $(11,12)$. In particular, autophagy promotes cell survival during nutrient starvation and growth factor deprivation, as well as in response to irradiation $(13,14)$. However, it is also known to contribute to apoptotic cell death by excessive activation of the self-degrading system $(10,15)$.

Reactive oxygen species (ROS), small molecules, including superoxide anion radical $\left(\mathrm{O}_{2}^{-}\right)$, hydrogen peroxide $\left(\mathrm{H}_{2} \mathrm{O}_{2}\right)$, and singlet oxygen $\left({ }^{1} \mathrm{O}_{2}\right)$, are derived from the mitochondrial respiratory chain complex during normal metabolism of oxygen or from various exogenous sources, such as smoking and certain pollutants (16). Many reports have demonstrated the induction of autophagy by ROS through several mechanisms, including regulation of the Atg4 family, mitochondrial electron transport chain and catalase (17-19). Consistently, antioxidant agents inhibit autophagosome formation and proteolysis (20). However, the role of ROS in cell death is ambivalent. For example, ROS have been known to contribute to cell death by the induction of apoptotic or autophagic cell death $(17,21)$, while certain studies have reported on ROS mediation of the survival pathway by the induction of autophagy under starvation conditions (18).

The root of Mori cortex, an oriental medicinal herb, has traditionally been used in Korea for the treatment of cutaneous inflammation, pulmonary asthma and congestion for thousands of years. According to recent studies, extracts of $M$. cortex have shown anti-inflammatory, anti-tumor, and hypoglycemic effects (22-24). However, the molecular mechanisms of its action as a death-inducer in cancer cells are not fully understood. From the viewpoint of the attributive channel theory, an oriental medicinal theory on the selective actions of herbal medicines on certain meridian channels and target organs, $M$. cortex mainly affects the functions of lungs (25). In this study, we investigated the anti-tumor effects of methylene chloride extracts of the $M$. cortex root (MEMC) in NCI-H460 NSCLC cells. In the process, we attempted to determine the mechanisms of MEMC-induced cell death through research on the roles of apoptosis and autophagy.

\section{Materials and methods}

Reagents and antibodies. Fetal bovine serum (FBS) and caspase activity assay kits were purchased from Gibco-BRL (Gaithersburg,MD,USA) and R\&DSystems (Minneapolis,MN), respectively. Monodancylcanaverin (MDC), 4,6-dianmidino2-phenylindole(DAPI),3-(4,5-dimethyl-2-thiazolyl)-2,5-diphnyl2H-tetrazolium bromide (MTT) and 5,5',6,6'-tetrachloro1,1',3,3'-tetraethylbenzimidazolyl carbocyanine iodide (JC-1) were purchased from Sigma (St. Louis, MO). An Annexin V fluorescein isothiocyanate (FITC) apoptosis detection kit and an enhanced chemiluminescence (ECL) kit were purchased from BD Pharmingen (San Diego, CA) and Amersham (Arlington Heights, IL), respectively. Control small interfering (siRNA) and LC3B siRNA were purchased from Cell Signaling Technology (Beverly, MA) and transfection reagent was purchased from Qiagen (Hilden, Germany). All antibodies were purchased from Santa Cruz Biotechnology (Santa Cruz, CA), except for LC3 antibody (MBL International, Woburn, MA).
Cell culture and preparation of MEMC. NCI-H460 cells were obtained from the American Type Culture Collection(Rockville, MD) and cultured in RPMI-1640 medium containing 10\% heat-inactivated FBS and $1 \%$ penicillin-streptomycin (Gibco $\mathrm{BRL}$ ) at $37^{\circ} \mathrm{C}$ in a humidified atmosphere containing $5 \% \mathrm{CO}_{2}$. For preparation of MEMC, dried roots of M. cortex (200 g) were chopped and extracted in 1.51 of $96 \%$ methylene chloride for 5 days at $100 \mathrm{rpm}, 35^{\circ} \mathrm{C}$. Powder, obtained by filtering and concentration of the extracts, was dissolved in dimethyl sulfoxide (DMSO) as a stock solution at a $200 \mathrm{mg} / \mathrm{ml}$ concentration and stored at $4^{\circ} \mathrm{C}$, and the stock solution was then diluted with medium to the desired concentration prior to use.

MTT assay. For investigation of cell viability, NCI-H460 cells were seeded in 6 -well plates at a density of $2.5 \times 10^{5}$ cells per well and stabilized for $24 \mathrm{~h}$. Cells were then treated with various concentrations of MEMC for $24 \mathrm{~h}$. MTT working solution $(0.5 \mathrm{mg} / \mathrm{ml})$ was then added to the culture plates, followed by continuous incubation at $37^{\circ} \mathrm{C}$ for $2 \mathrm{~h}$. The culture supernatant was removed from the wells, and DMSO was added in order to completely dissolve the formazan crystals. Absorbance of each well was measured at a wave length of $540 \mathrm{~nm}$ using an ELISA reader.

Nuclear staining with DAPI. Cells were harvested and washed once with phosphate-buffered saline (PBS) and fixed with $3.7 \%$ paraformaldehyde (Sigma) in PBS for $30 \mathrm{~min}$ at room temperature. Fixed cells were then washed once with PBS and attached on glass slides using cytospin (Shandon, Pittsburgh, PA). After staining with a DAPI solution $(2.5 \mu \mathrm{g} / \mathrm{ml})$ for $20 \mathrm{~min}$ at room temperature, cells were washed twice with PBS and changes of the nucleus were analyzed using a fluorescence microscope (Carl Zeiss, AG, Germany).

Flow cytometry analysis for measurement of sub-Gl phase. After treatment with MEMC, cells were harvested and washed twice with PBS, and a DNA reagent kit (Cycle TEST ${ }^{\text {тм }}$ PLUS kit, Becton-Dickinson, San Jose, CA) was used for staining of the DNA content of cells, according to the manufacturer's instructions. Flow cytometric analyses were performed using a flow cytometer and the relative DNA content was determined by CellQuest software, based on the presence of red fluorescence.

Annexin V/PI binding assay. To determine the magnitude of apoptosis induced by MEMC,MEMC-treated cells were washed with PBS, followed by treatment using the Annexin V-FITC apoptosis detection kit, containing FITC-conjugated Annexin $\mathrm{V}$ and propidium iodide (PI), according to the manufacturer's instructions. Following incubation for $20 \mathrm{~min}$ at room temperature, Annexin V-positive apoptotic cells were analyzed using a flow cytometer (26).

Measurement of MMP. MMP was determined using the dualemission potential-sensitive probe, JC-1. MEMC-treated cells were collected and incubated with $10 \mu \mathrm{M} \mathrm{JC}-1$ for $20 \mathrm{~min}$ at $37^{\circ} \mathrm{C}$ in the dark. Cells were then washed once with PBS and analyzed using a DNA flow cytometer (27).

Determination of caspase activity. The activities of caspases were determined by colorimetric assay kits, which contain 
synthetic tetrapeptides [Asp-Glu-Val-Asp (DEAD) for caspase-3, Ile-Glu-Thr-Asp (IETD) for caspase-8 and Leu-GluHis-Asp (LEHD) for caspase-9] labeled with p-nitroaniline (pNA). MEMC-treated cells were harvested and lysed in the supplied lysis buffer. Supernatants were then collected and incubated with the supplied reaction buffer, DTT and DEAD-pNA, IETD-pNA or LEHD-pNA as substrates at $37^{\circ} \mathrm{C}$. Reaction activities were measured by investigation of absorbance at $405 \mathrm{~nm}$ using an ELISA reader.

Immunofluorescence analysis. Translocation of apoptosisinducing factor (AIF) in nuclei was detected and analyzed by fluorescence microscopy using a fluorescence microscope. NCI-H460 cells were grown on glass cover slips for $24 \mathrm{~h}$, followed by treatment with MEMC $(75 \mu \mathrm{g} / \mathrm{ml})$ for a further $24 \mathrm{~h}$. Cells were fixed with $3.7 \%$ paraformaldehyde, treated with $0.2 \%$ Triton X-100, and blocked with $2 \%$ bovine serum albumin. Cells were then incubated with anti-AIF antibody, FITC-conjugated donkey anti-rabbit IgG, and DAPI, and examined using a fluorescence microscope (Carl Zeiss).

Autophagic vacuole staining with MDC. For visualization of autophagosomes, cells were fixed with $3.7 \%$ paraformaldehyde in PBS for $30 \mathrm{~min}$ and incubated with $50 \mu \mathrm{M}$ of MDC for $30 \mathrm{~min}$ at room temperature. Cells were then washed twice with PBS, followed by immediate observation under a fluorescence microscope.

Observation of ROS generation. For measurement of ROS generation, cells were treated with MEMC for various periods and the medium was discarded; cells were then incubated with new culture medium containing 5-(and 6)-carboxy-2'7'-dichlorodihydrofluorescein diacetate (DCFDA, $10 \mu \mathrm{M}$ ) at $37^{\circ} \mathrm{C}$ in the dark for $20 \mathrm{~min}$. Cell lysates were used for evaluation of ROS generation using a flow cytometer (28). For observation of ROS generation, using a fluorescence microscope, cells were harvested and washed once with PBS and fixed with $3.7 \%$ paraformaldehyde in PBS for 30 min at room temperature. Fixed cells were washed once with PBS and attached on glass slides using cytospin. Cells were then washed twice with PBS and ROS generation was observed by a fluorescence microscope.

Protein extraction and western blot analysis. Cells were collected and lysed with lysis buffer $(20 \mathrm{mM}$ sucrose, $1 \mathrm{mM}$ EDTA, $20 \mu \mathrm{M}$ Tris-Cl, pH 7.2, $1 \mathrm{mM}$ DTT, $10 \mathrm{mM} \mathrm{KCl}$, $1.5 \mathrm{mM} \mathrm{MgCl}, 5 \mu \mathrm{g} / \mathrm{ml}$ pepstatin A, $10 \mu \mathrm{g} / \mathrm{ml}$ leupeptin, and $2 \mu \mathrm{g} / \mathrm{ml}$ aprotinin) containing protease inhibitors. Protein concentrations were quantified using a Bio-Rad protein assay (Bio-Rad Laboratories, Hercules, CA), according to the manufacturer's instructions. For western blot analysis, an equal amount of protein was loaded on an SDS-polyacrylamide gel and transferred to a nitrocellulose membrane (Schleicher \& Schuell, Keene, NH) by electroblotting. Blots were probed with the specific primary antibodies and enzyme-linked secondary antibodies, and were visualized using an ECL kit according to the manufacturer's instructions. The mitochondrial extract and cytoplasmic extract were obtained using nuclear and cytoplasmic extraction reagents (Thermo Scientific, San Jose, CA), according to the manufacturer's instructions. Western blot analysis was performed as mentioned above.
Small interfering RNA transfection. NCI-H460 cells were seeded in a 6 -well plate at an initial density of $1.5 \times 10^{5}$ cells per well. After $24 \mathrm{~h}$ of stabilization, cells were transfected with $100 \mathrm{nM}$ of small interfering RNA (siRNA) against human LC3B or control siRNA using transfection reagent (Qiagen), according to the manufacturer's instructions. Following $24 \mathrm{~h}$ of transfection, cells were treated with MEMC for another $24 \mathrm{~h}$.

Statistical analysis. Unless otherwise indicated, each result is expressed as the means \pm SD of data obtained from triplicate experiments. A paired Student's t-test was used for statistical analysis. Differences at $\mathrm{P}<0.05$ were considered statistically significant.

\section{Results}

MEMC treatment causes apoptotic cell death in NCI-H46O cells. To examine the growth-inhibitory effects of MEMC, NCI-H460 cells were treated with various concentrations of MEMC for $24 \mathrm{~h}$. As shown in Fig. 1A and B, a concentrationand time-dependent decrease in cell viability was observed after MEMC treatment. Morphological observances also showed a diminished cell density and an increased number of floating cells (Fig. 1C), indicating the possibility that the MEMC-induced decrease of cell viability was by cell death. To determine which form of cell death was induced by MEMC in NCI-H460 cells, we performed nuclear staining with DAPI and flow cytometry analysis for sub-G1 phase DNA content and Annexin V-positive cells, indicators of apoptotic cells. As indicated in Fig. 1D, cells treated with MEMC displayed apoptotic morphological changes, including chromatin condensation and formation of apoptotic bodies, suggesting that MEMC-induced cell death occurred via apoptosis. Flow cytometry analyses for sub-G1 population and Annexin V-FITC/PI double staining assay also showed a concentration-dependent increase of apoptotic cells (Fig. 1E and F). These results clearly indicate that the MEMC-induced reduction of viability is associated with the induction of apoptosis.

MEMC modulates both extrinsic and intrinsic pathways leading to loss of MMP in NCI-H460 cells. There are two classical pathways in apoptosis: an extrinsic pathway, which requires transmembrane death receptor-mediated interactions, and an intrinsic pathway, which initiates apoptosis via mitochondrialmediated stimuli. Thus, we then attempted to determine which pathway was involved in MEMC-treated NCI-H460 cells. The results showed marked concentration-dependent upregulation of cellular levels of death receptor (DR)4, DR5, and FasL proteins, major members of the extrinsic pathway, after MEMC treatment (Fig. 2A). However, levels of anti-apoptotic Bcl-2 and $\mathrm{Bcl}-\mathrm{xL}$ proteins, which play critical roles in maintaining the stability of the mitochondrial membrane in the intrinsic pathway, showed a concentration-dependent decrease and a concomitant loss of MMP was also observed in MEMC-treated cells (Fig. 2B and C). Of particular interest, pro-apoptotic Bax levels showed a slight decrease in response to MEMC treatment (Fig. 2B). This result is quite controversial, as Bax is considered to increase during the apoptotic process. However, through mitochondrial fractionation assay, we observed that the levels of the Bax proteins increased in the mitochondria 

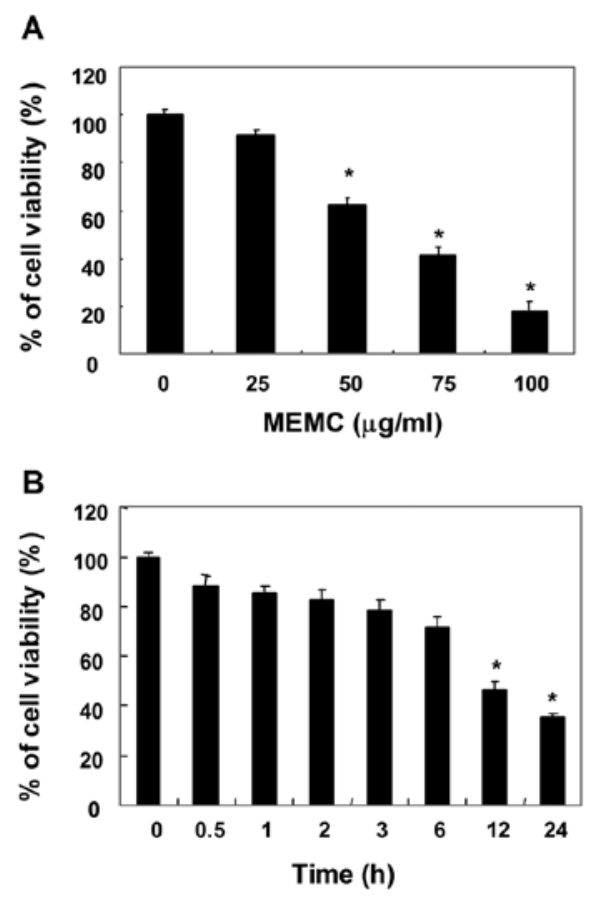

$\operatorname{MEMC}(\mu \mathrm{g} / \mathrm{ml})$

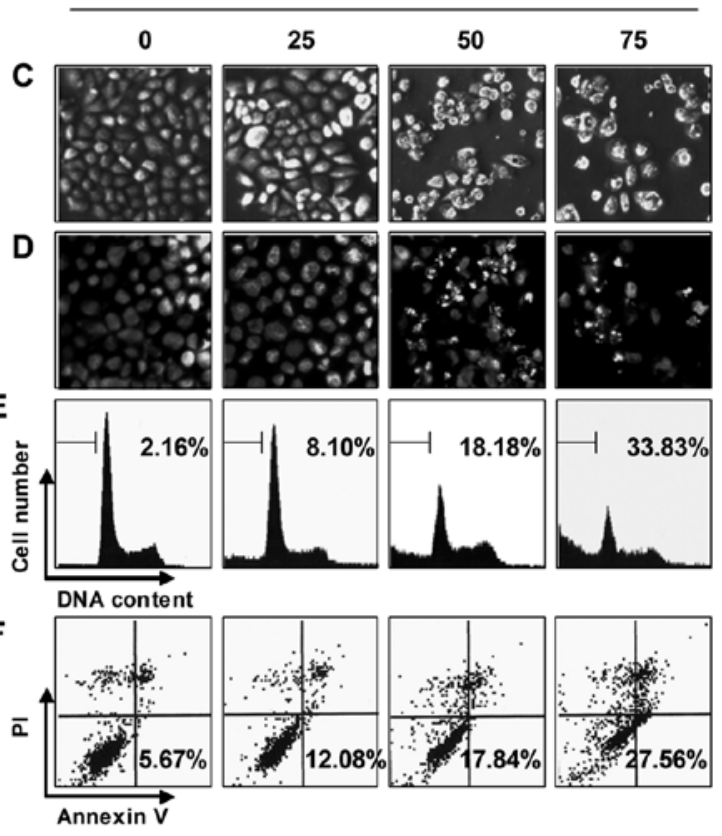

Figure 1. MEMC treatment inhibits cell growth and causes apoptotic cell death in NCI-H460 cells. NCI-H460 cells were seeded in a 6-well plate at an initial density of $2.5 \times 10^{5}$ cells per well. After $24 \mathrm{~h}$ of stabilization, (A) cells were treated with various concentrations of MEMC for $24 \mathrm{~h}$ or (B) incubated with the indicated concentration of MEMC $(75 \mu \mathrm{g} / \mathrm{ml})$ for various periods. Cell viability was determined by MTT assay. Results are expressed as the percentage of the vehicle treated control \pm SD of three separate experiments. A Student's t-test ("P $<0.05$ vs. untreated control) was used for the determination of significance. (C) Cell morphology was visualized using an inverted microscope. Magnification, x200. (D) To investigate morphological changes of nuclei, cells were stained with DAPI solution. Stained nuclei were then observed under a fluorescence microscope using a blue filter. Magnification, $\mathrm{x} 400$. (E) To quantify the degree of apoptosis induced by MEMC, cells were evaluated for sub-G1 DNA content, which represents the fractions undergoing apoptotic DNA degradation, using a flow cytometer. (F) Cells were stained with FITC-conjugated Annexin V plus PI and evaluated using a flow cytometer. The apoptotic rate was calculated by the percentage of early apoptotic (Annexin $\mathrm{V}^{+} / \mathrm{PI}$ ) cells plus the percentage of late apoptotic (Annexin $\mathrm{V}^{+} / \mathrm{PI}^{+}$) cells. Results are expressed as a percentage of the vehicle treated control \pm SD of two separate experiments.

and decreased in the cytosol, while cytochrome $c$ levels showed a reverse tendency (Fig. 2D). These data suggest that the translocation of Bax from the cytosol to the mitochondria results in the loss of MMP and consistent release of cytochrome $c$, which exists in the mitochondria under normal conditions.

We then examined the effects of MEMC on Bid expression, a BH3-only protein, in NCI-H460 cells. Bid cleavage was assessed as a reduction in whole Bid protein as the antibody used in this study recognized only the whole Bid molecule, but not the cleavage product. Treatment with $25 \mu \mathrm{g} / \mathrm{ml}$ of MEMC did not induce cleavage of Bid. However, there was a greater reduction of Bid at 50 and $75 \mu \mathrm{g} / \mathrm{ml}$ MEMC (Fig. 2B), suggesting that signals from the activated extrinsic pathway changed Bid to tBid, which contributes to the loss of MMP and initiates the intrinsic pathway. Therefore, these results demonstrate that MEMC modulates both the extrinsic and intrinsic pathways in NCI-H460 cells.

MEMC activates caspases and inhibits IAP family proteins in NCI-H460 cells. In order to determine whether or not caspase activation is involved in MEMC-treated NCI-H460 cells, the expression levels and activities of several caspases were examined. The results from immunoblot analysis showed that MEMC treatment induced a concentration-dependent decrease in the levels of procaspase-3, -8 and -9 proteins (Fig. 3A). To further quantify the proteolytic activation of the caspases, we determined that lysates equalized for protein content were obtained from cells treated with MEMC using DEVD-pNA, IETD-pNA and LEHD-pNA as substrates for caspase-3, -8, and -9 , respectively. As shown in Fig. 3C, treatment with MEMC resulted in a significant concentration-dependent increase in the activities of caspase- $3,-8$ and -9 , which was associated with a decrease in the levels of IAP family proteins, which bind to caspases and suppress caspase activation, such as XIAP and cIAP-2, but not cIAP-1 (Fig. 3B). In addition, MEMC treatment led to progressive proteolytic cleavage of poly(ADP-ribose) polymerase (PARP), a well-known substrate protein of activated caspase-3, demonstrating that MEMCinduced apoptosis was associated with caspase activation (Fig. 3A).

MEMC induces caspase-dependent apoptosis in NCI-H46O cells. We then blocked caspase subtype activity using specific caspase subtype inhibitors in order to determine whether MEMC-induced apoptosis occurred via a caspase-dependent mechanism. As shown in Fig. 4A, z-DEVD-fmk, z-IETD-fmk and z-LEHD-fmk and caspase-3, -8 and -9 inhibitors, respectively, induced significant suppression of MEMC-induced apoptosis. In particular, z-VAD-fmk, a pan-caspase inhibitor, induced almost the complete blockade of MEMC-induced apoptosis in NCI-H460 cells (Fig. 4A). Western blot analysis also showed that $\mathrm{z}$-VAD-fmk inhibited the caspase activation induced by MEMC, and suppressed the cleavages of PARP and Bid. The MEMC-induced decrease of the anti-apoptotic 
A

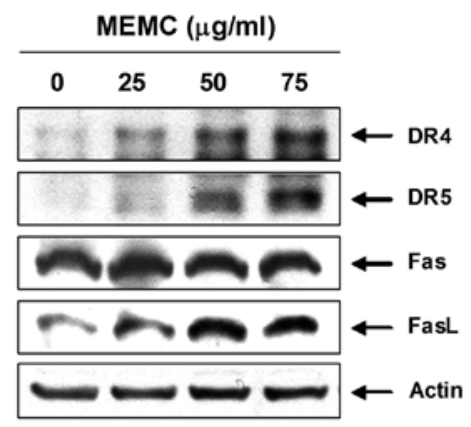

C

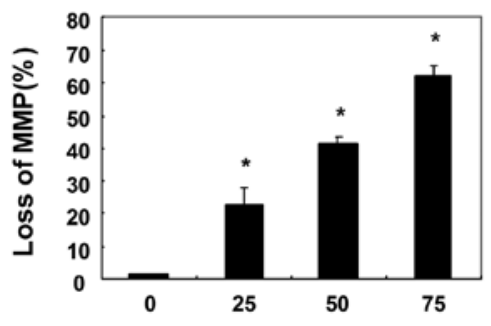

B

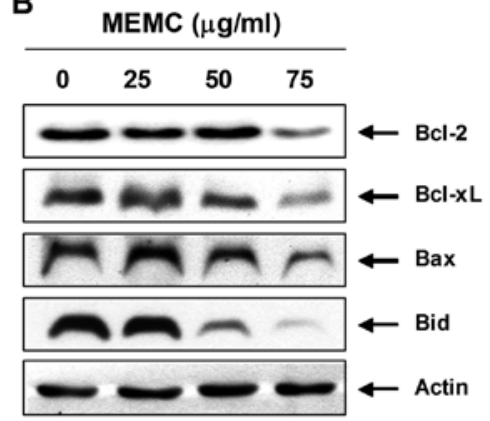

D

MEMC $(75 \mu \mathrm{g} / \mathrm{ml})$

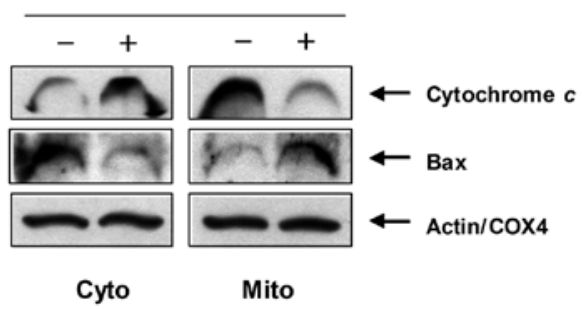

Figure 2. MEMC modulates both extrinsic and intrinsic pathways leading to loss of MMP in NCI-H460 cells. Following incubation with MEMC for $24 \mathrm{~h}, \mathrm{NCI}-\mathrm{H} 460$ cells were lysed, and cellular proteins were separated by SDS-polyacrylamide gels and transferred onto nitrocellulose membranes. (A) Membranes were probed with the indicated antibodies against extrinsic pathway-related or (B) intrinsic pathway-related proteins. Proteins were visualized using an ECL detection system. Actin was used as an internal control. (C) Cells under the same conditions as (A and B) were collected and incubated with JC-1 (10 $\mu \mathrm{M}$ ) for $20 \mathrm{~min}$ at $37^{\circ} \mathrm{C}$ in the dark. Cells were then washed once with PBS and analyzed by a DNA flow cytometer. Results are expressed as the means \pm SD of three independent experiments. The statistical significance of the results was analyzed by a Student's t-test (" $\mathrm{P}<0.05$ vs. untreated control). (D) Mitochondrial proteins and cytosolic proteins were extracted and analyzed by western blotting. Actin and COX4 were used as the internal controls for the mitochondrial fractions and the cytosolic fraction, respectively. MMP, mitochondrial membrane potential.

A

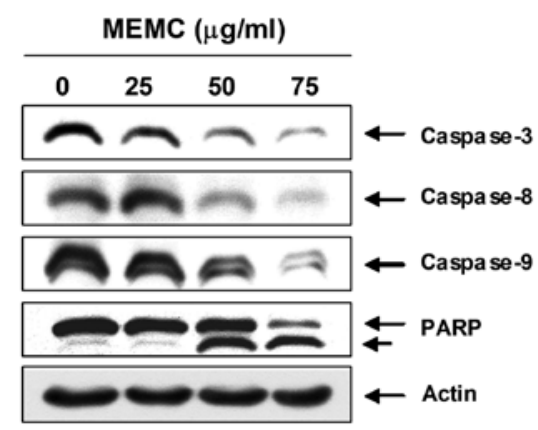

B

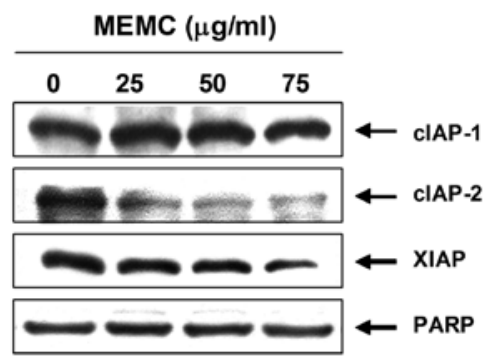

C

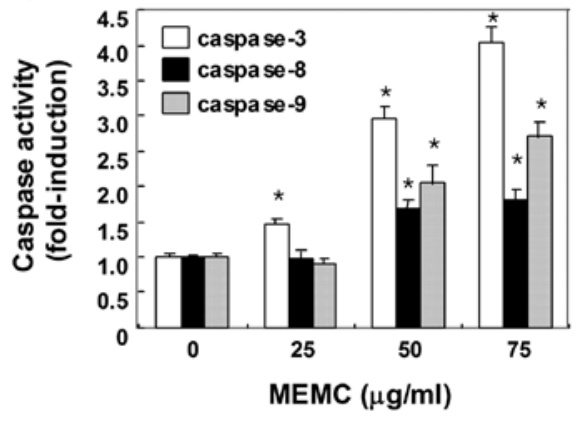

Figure 3. MEMC activates caspases and inhibits IAP family proteins in NCI-H460 cells. (A and B) NCI-H460 cells were incubated with the indicated concentration of MEMC for $24 \mathrm{~h}$. Cells were then lysed, and cellular proteins were separated by SDS-polyacrylamide gels and transferred onto nitrocellulose membranes. Membranes were probed with the indicated antibodies. Proteins were visualized using an ECL detection system. Actin was used as the internal control. (C) Cell lysates obtained from cells grown under the same conditions as (A) were assayed for in vitro caspase-3, -8, and -9 activity using DEVD-pNA, IETD-pNA, and LEHD-pNA, respectively, as substrates. Relative fluorescence products were measured using an ELISA reader. Results are expressed as the means \pm SD of three independent experiments. Statistical significance of the results was analyzed by a Student's t-test ( $\mathrm{P}<0.05$ vs. untreated control). 


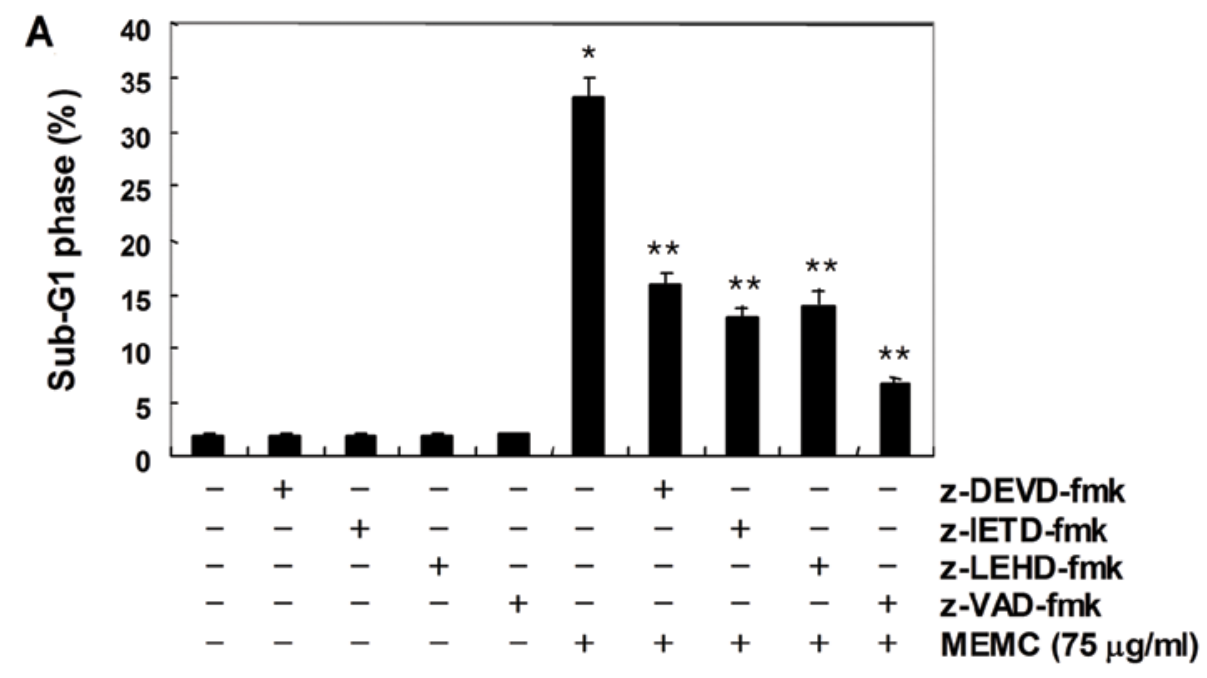

B

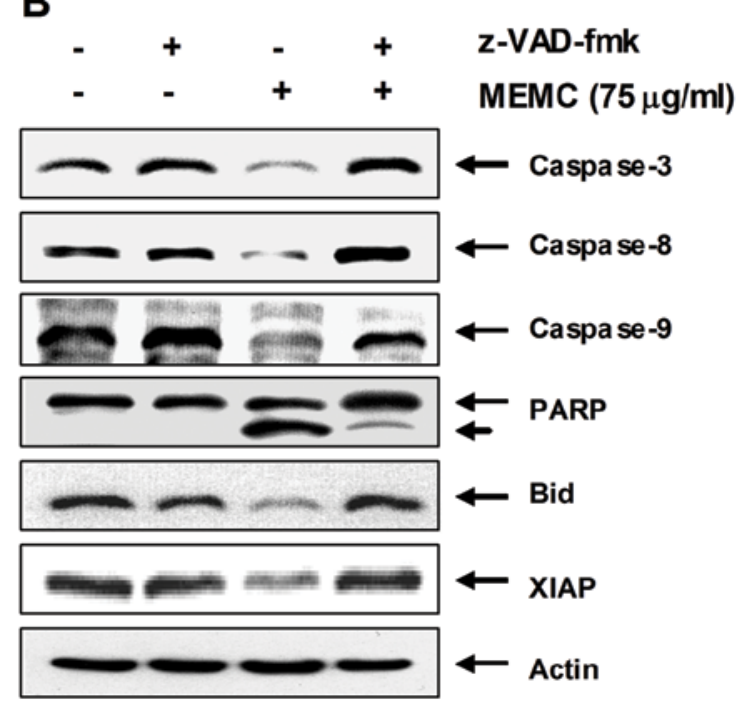

C

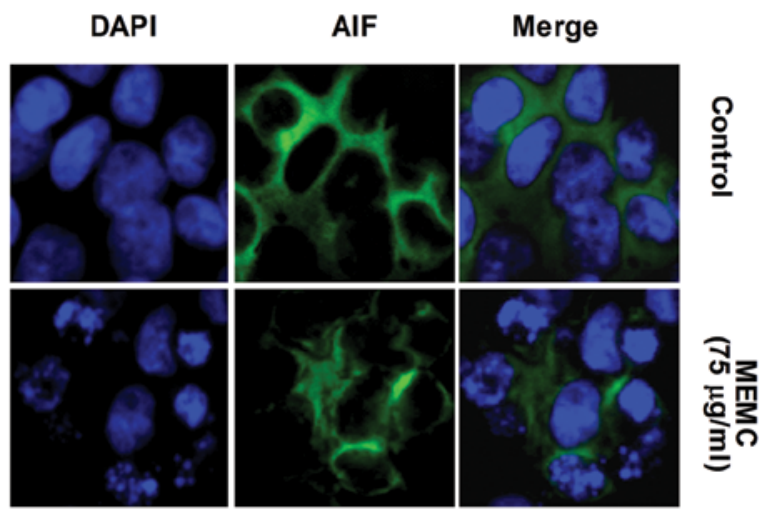

Figure 4. MEMC induces caspase-dependent apoptosis in NCI-H460 cells. (A) NCI-H460 cells were incubated with or without $75 \mu \mathrm{g} / \mathrm{ml}$ of MEMC for $24 \mathrm{~h}$ after $1 \mathrm{~h}$ pre-treatment with or without $50 \mu \mathrm{M}$ of caspase inhibitors (z-DEVD-fmk, z-IETD-fmk, z-LEHD-fmk, and z-VAD-fmk for caspase-3, -8 -9, and pan-caspase, respectively). To quantify the degree of apoptosis, cells were evaluated by flow cytometry for sub-G1 DNA content. Results are expressed as the means \pm SD of three independent experiments. Statistical significance of the results was analyzed by a Student's t-test ( ${ }^{*} \mathrm{P}<0.05$ vs. untreated control, ${ }^{* *} \mathrm{P}<0.05$ vs. MEMC-treated cells). (B) Cellular proteins extracted from cells grown under the same conditions as (A) were separated by SDS-polyacrylamide gels and transferred onto nitrocellulose membranes. Membranes were probed with the indicated antibodies. Proteins were visualized using an ECL detection system. Actin was used as an internal control. (C) Following incubation of cells under the same conditions as (A), localization of AIF was visualized with fluorescence microscopy after immunofluorescence staining with anti-AIF antibody (green). Cells were then stained with DAPI for visualization of nuclei (blue). Results are representative of those obtained from three independent experiments.

XIAP was also recovered by pre-treatment with z-VAD-fmk (Fig. 4B)

Although z-VAD-fmk caused a significant blockade of apoptosis, we performed further experiments concerning the minor possibility that MEMC-induced apoptosis was triggered via a caspase-independent pathway. AIF, located in the mitochondrial intermembrane space, is a representative protein that triggers apoptosis through translocation from the mitochondria to the nucleus, resulting in caspase-independent chromatin condensation (29,30). However, as shown in Fig. 4C, AIF did not translocate to the nucleus after MEMC treatment, weakening the possibility of involvement of the caspase-independent pathway. These data indicate that the activation of caspases is essential for MEMC-induced apoptosis in NCI-H460 cells.
MEMC induces autophagy in NCI-H460 cells. We observed that small vacuoles were increased in both a time- (data not shown) and concentration-dependent manner after MEMC treatment (Fig. 5A). Under the hypothesis that these vacuoles might be autophagosomes, MDC, which is known to be a specific dye for autophagosomes, was used (31). As shown in Fig. 5B, MEMC-induced cytoplasmic vacuoles were stained by MDC and the number of stained vacuoles was increased in a concentration-dependent manner, indicating that the morphological changes induced by MEMC were related to autophagy.

Among regulators of autophagy, beclin-1 and LC3 are representative proteins. Beclin-1 plays an important role in the formation of a complex responsible for autophagic vesicle 


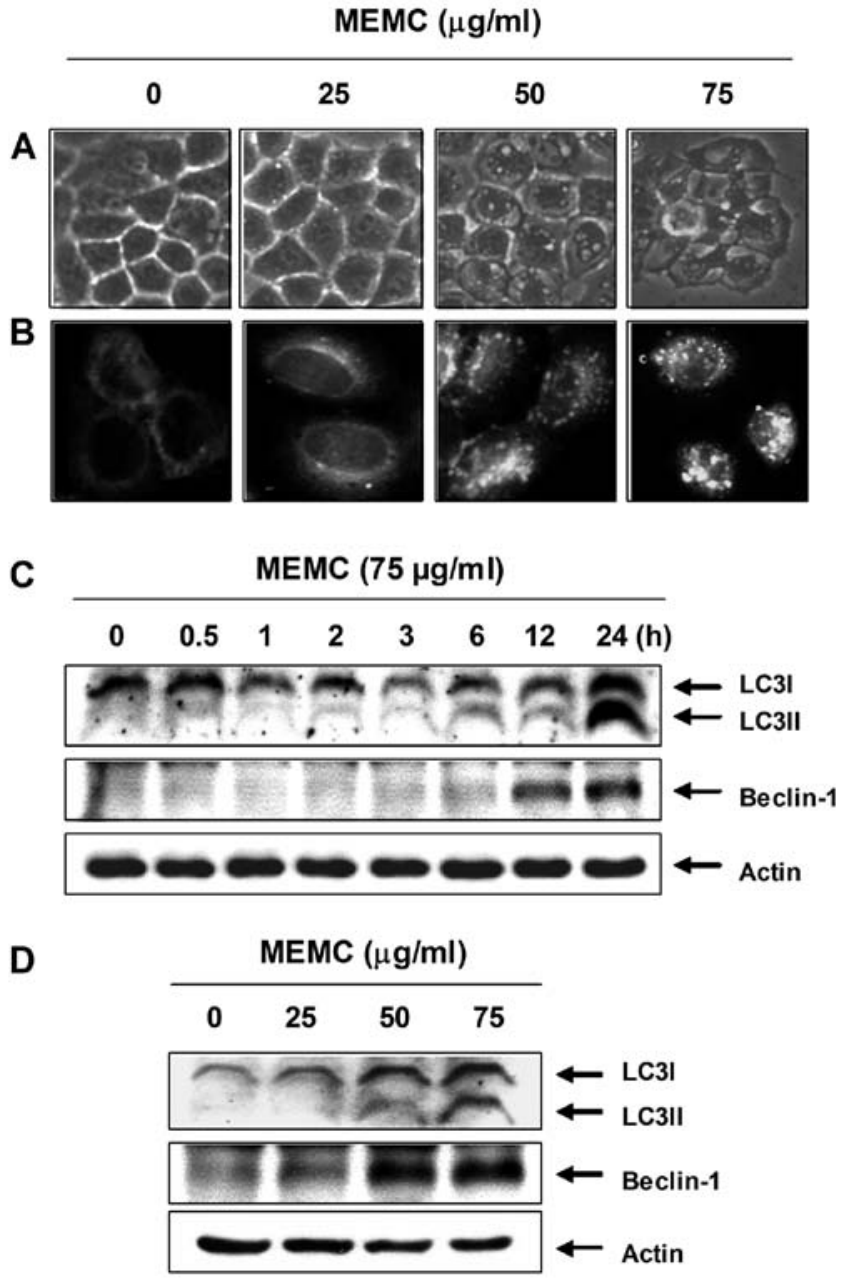

Figure 5. MEMC treatment induces autophagy in NCI-H460 cells. NCI-H460 cells were (B and D) treated with the indicated concentrations of MEMC for $24 \mathrm{~h}(\mathrm{~A}, \mathrm{~B}$ and D) or (C) incubated with $75 \mu \mathrm{g} / \mathrm{ml}$ of MEMC for the indicated periods. (A) Cellular morphologies were photographed by the microscope. Magnification, x200. (B) For visualization of autophagosomes, cells were fixed with $3.7 \%$ paraformaldehyde in PBS and incubated with $50 \mu \mathrm{M}$ of MDC for $30 \mathrm{~min}$ at room temperature. Cells were then washed twice with PBS and observed under a fluorescence microscope. Magnification, $\mathrm{x} 400$. (C and D) Cells were lysed, and cellular proteins were separated by SDS-polyacrylamide gels and transferred onto nitrocellulose membranes. Membranes were probed with anti-LC3 and ant-beclin-1 antibodies. Proteins were visualized using an ECL detection system. Actin was used as the internal control.

nucleation (32). Upon formation of autophagosomes, a cytosolic LC3 converts its form from LC3I to LC3II by proteases, and LC3II was recruited to the autophagosome membrane. Thus, accumulations of beclin-1 and LC3II proteins can be used as autophagosome markers (33). As indicated in Fig. 5C and $\mathrm{D}$, the results of western blot analysis showed upregulation of LC3II and beclin-1 in MEMC-treated cells. These results are consistent with data obtained by morphological observances and MDC staining, demonstrating that MEMC induces autophagy as well as apoptosis in NCI-H460 cells.

Inhibition of autophagy enhances MEMC-induced apoptotic cell death. The question of whether autophagy is involved in cell death or in cell survival is still under controversy. To determine the role of autophagy in MEMC-treated NCI-H460 cells,
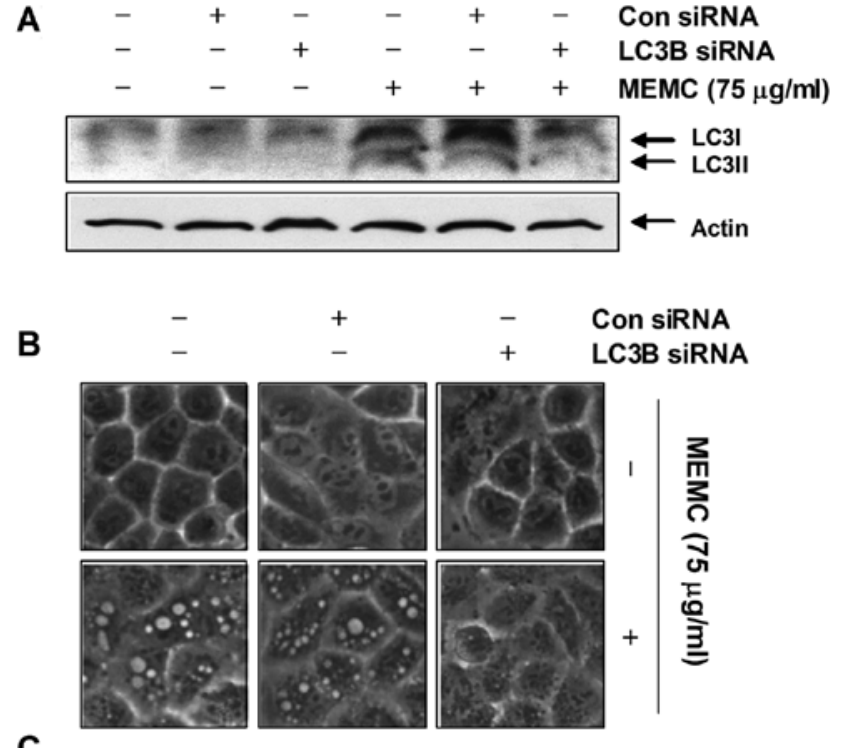

C

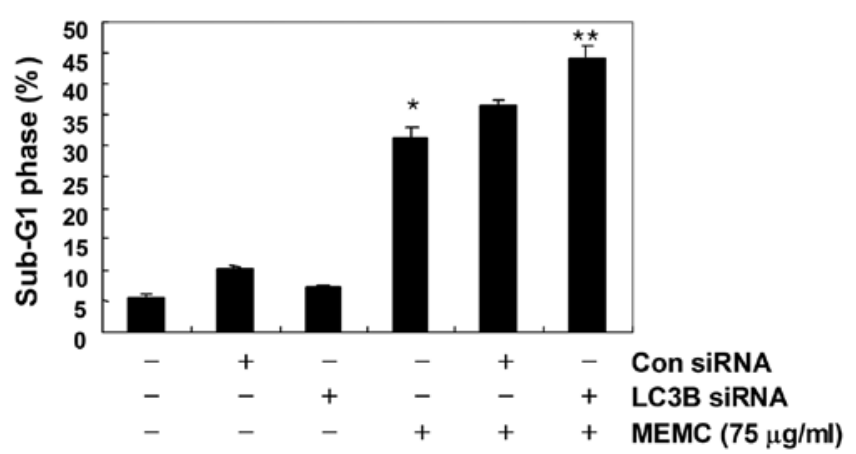

Figure 6. Suppression of autophagy by LC3 siRNA enhances the rates of apoptosis in NCI-H460 cells. NCI-H460 cells were seeded in a 6-well plate at an initial density of $1.5 \times 10^{5}$ cells per well. After $24 \mathrm{~h}$ of stabilization, cells were transfected with $100 \mathrm{nM}$ of small siRNA against human LC3B or control siRNA using transfection reagent. After $24 \mathrm{~h}$ of transfection, cells were treated with MEMC ( $75 \mu \mathrm{g} / \mathrm{ml})$ for another $24 \mathrm{~h}$. (A) Cellular proteins were lysed and separated by SDS-polyacrylamide gels and then transferred onto nitrocellulose membranes. Membranes were probed with anti-LC3 antibody. Proteins were visualized using an ECL detection system. Actin was used as an internal control. (B) Cellular morphologies were photographed by the microscope. Magnification, $x$ 400. (C) Cells were evaluated by flow cytometry for sub-G1 DNA content. Results are expressed as the means \pm SD of three independent experiments. Statistical significance of the results was analyzed by a Student's t-test ( $\mathrm{P}<0.05$ vs. untreated control, ${ }^{* *} \mathrm{P}<0.05$ vs. MEMC-treated cells).

cells were transiently transfected with LC3B siRNA followed by MEMC treatment. As a result, western blot analysis showed that LC3 siRNA decreased the level of LC3II induced by MEMC treatment, while control siRNA had no effect on the expression of LC3 (Fig. 6A). LC3 siRNA also suppressed MEMC-induced accumulation of autophagosomes (Fig. 6B), which is in exact accordance with the decreased expression of LC3II, the marker of autophagosomes. Of particular interest, as shown in Fig. 6C, the inhibition of autophagy by LC3 siRNA enhanced MEMC-induced apopototic cell death detected by flow cytometry. These results indicate that MEMC-induced autophagy suppresses apoptotic cell death in NCI-H460 cells.

To reconfirm the role of autophagy in MEMC-treated cells, 3MA, an autophagy inhibitor, was also used, which is known to block autophagy by suppressing the formation of 
A

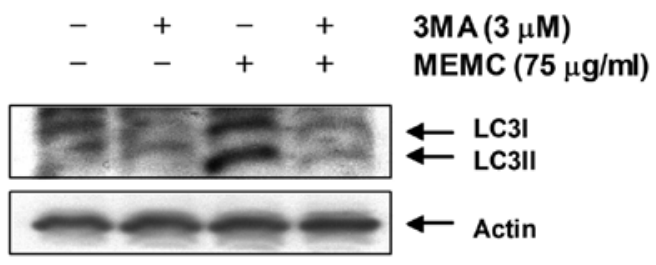

B
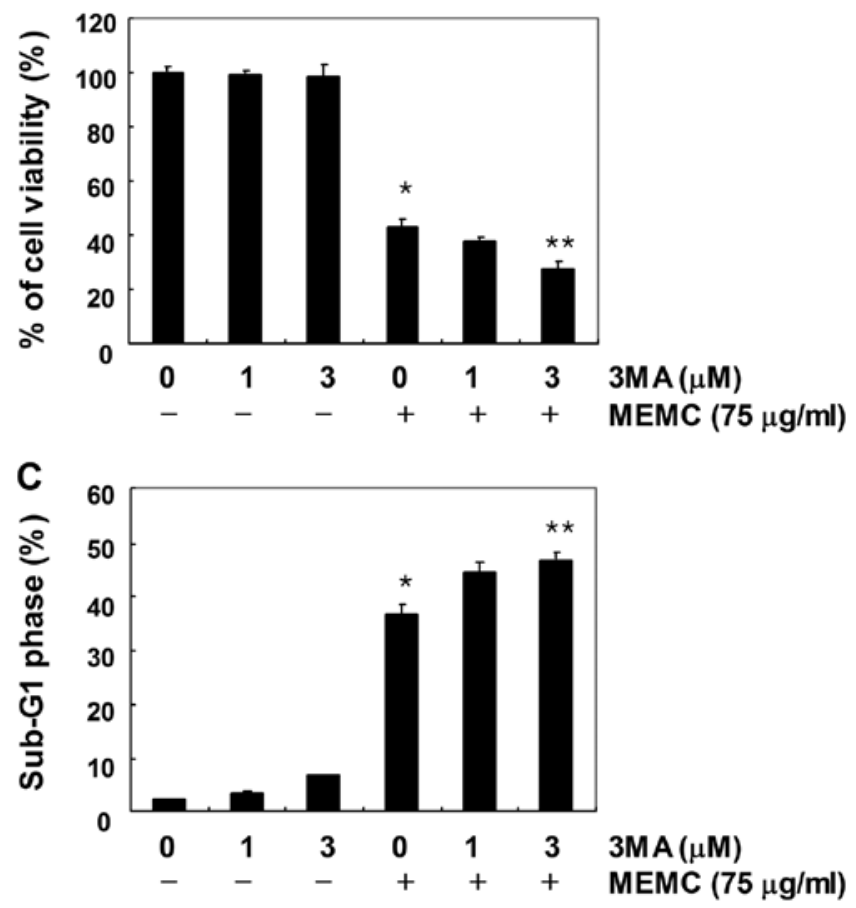

Figure 7. Inhibition of autophagy by $3 \mathrm{MA}$ enhances the rate of apoptosis in NCI-H460 cells. NCI-H460 cells were seeded in a 6-well plate at an initial density of $2.5 \times 10^{5}$ cells per well. After $24 \mathrm{~h}$ of stabilization, cells were pretreated with the indicated concentrations of $3 \mathrm{MA}$ for $2 \mathrm{~h}$ and challenged with MEMC $(75 \mu \mathrm{g} / \mathrm{ml})$ for $24 \mathrm{~h}$. (A) Cells were lysed and the levels of LC3 proteins were analyzed by western blotting. (B and C) Cell viability and sub-G1 contents were measured by MTT assay and flow cytometer. Results are expressed as the means \pm SD of three independent experiments. Statistical significance of the results was analyzed by a Student's t-test (" $\mathrm{P}<0.05$ vs. untreated control, ${ }^{* *} \mathrm{P}<0.05$ vs. MEMC-treated cells).

autophagosomes. Our results indicate that treatment with 3MA inhibitz autophagosome formation, supported by the decreased LC3II level (Fig. 7A). The suppression of autophagy by $3 \mathrm{MA}$ resulted in reduced cell viability (Fig. 7B) and enhanced MEMC-induced apoptosis (Fig. 7C). Taken together, these findings demonstrate that MEMC-induced autophagy may function as a survival mechanism against apoptotic cell death in NCI-H460 cells.

MEMC treatment generates ROS, resulting in loss of MMP in NCI-H460 cells. ROS are known to regulate cell proliferation, apoptosis, necrosis and autophagy (34). ROS can trigger the abrupt loss of MMP, and the collapse of mitochondria can cause a mitochondrial burst of ROS production (35). We hypothesized that ROS may be an important regulator of MEMC-induced cell death. To confirm this hypothesis, we first attempted to determine whether MEMC treatment causes ROS generation using flow cytometry and a fluorescence microscope. As shown

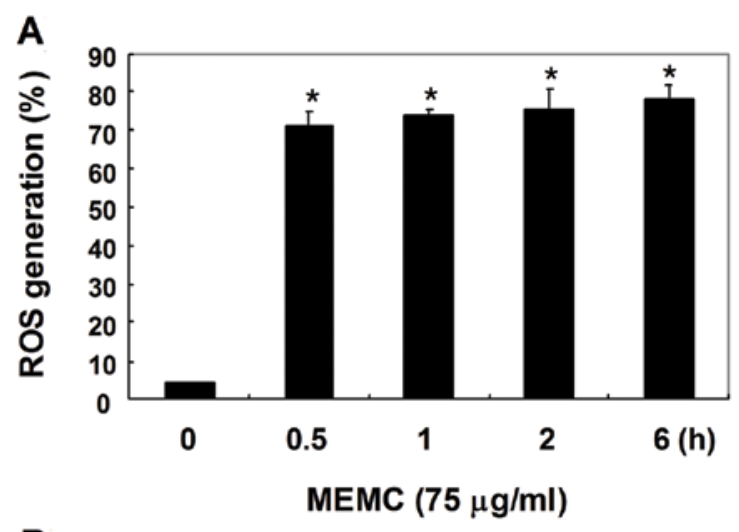

B
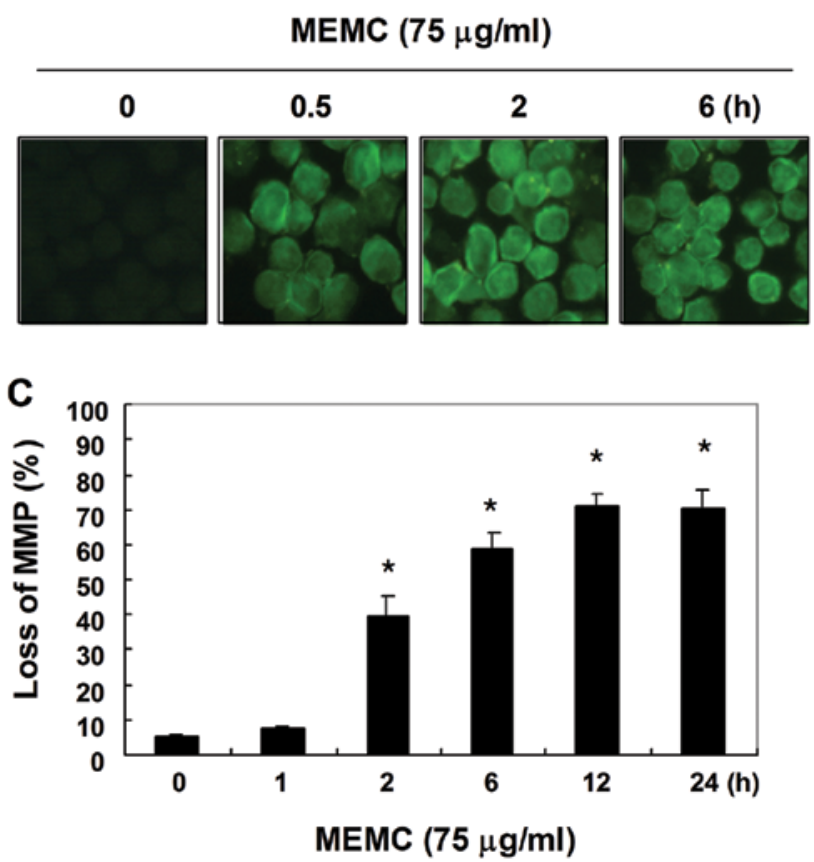

Figure 8. MEMC treatment generates ROS resulting in loss of MMP in NCI-H460 cells. NCI-H460 cells were seeded in a 6-well plate at an initial density of $2.5 \times 10^{5}$ cells per well. After $24 \mathrm{~h}$ of stabilization, cells were challenged with $75 \mu \mathrm{g} / \mathrm{ml}$ of MEMC for the indicated times. (A) The medium was discarded and cells were incubated at $37^{\circ} \mathrm{C}$ in the dark for 20 min with new culture medium containing DCFDA $(10 \mu \mathrm{M})$. ROS generation was measured by flow cytometry. (B) Cells were harvested and washed twice with PBS, followed by fixation with $3.7 \%$ paraformaldehyde in PBS for $30 \mathrm{~min}$ at room temperature. After centrifugation, the supernatants were discarded and the cells, stained with DCFCA, were attached on glass slides using cytospin. Cells were subsequently incubated with FITC-conjugated anti-rabbit IgG and washed with PBS. These experiments were performed twice independently, with similar results obtained in each experiment. (C) Cells were collected, incubated with JC-1 $(10 \mu \mathrm{M})$ for $20 \mathrm{~min}$ at $37^{\circ} \mathrm{C}$ in the dark, washed once with PBS, and then analyzed using a DNA flow cytometer. Results are expressed as the means \pm SD of three independent experiments. Statistical significance of the results was analyzed by a Student's t-test ( ${ }^{*} \mathrm{P}<0.05$ vs. untreated control).

in Fig. 8A and B, ROS generation was first detected at $30 \mathrm{~min}$ after MEMC treatment, and it lasted over $6 \mathrm{~h}$. Of particular interest, a significant loss of MMP was observed $2 \mathrm{~h}$ after MEMC treatment, indicating that ROS generation is an early event followed by mitochondrial dysfunction (Fig. 8C). These results indicate that MEMC treatment induces ROS generation and that ROS accumulation may occur as a result of the loss of MMP in NCI-H460 cells. 
A

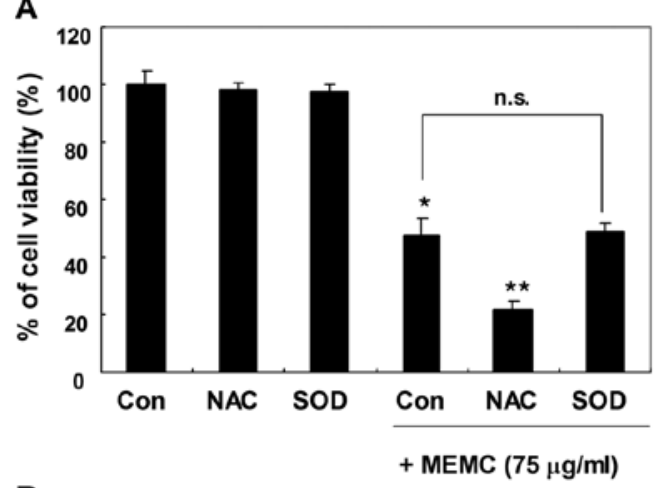

B

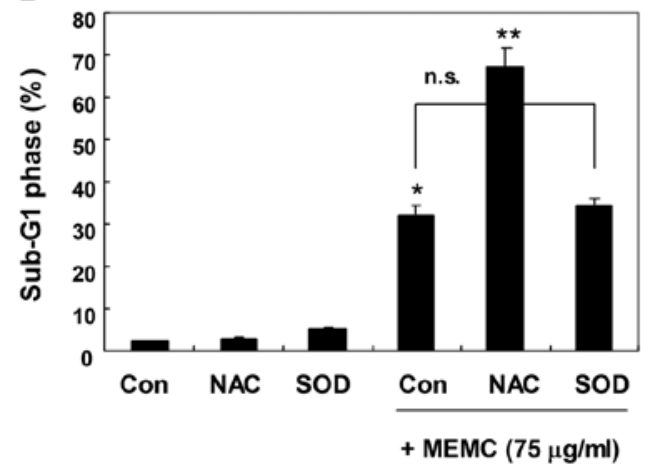

C

Con NAC SOD Con NAC SOD
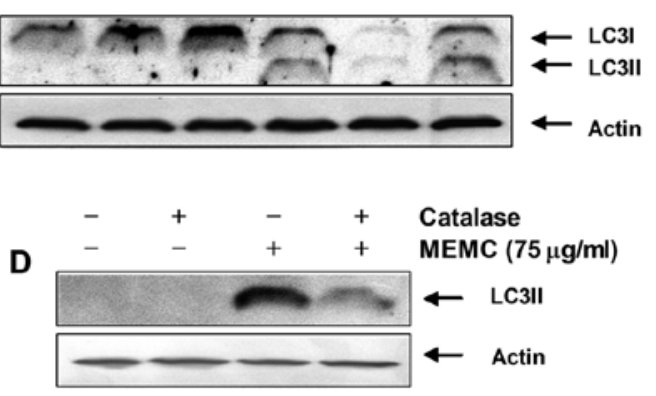

E

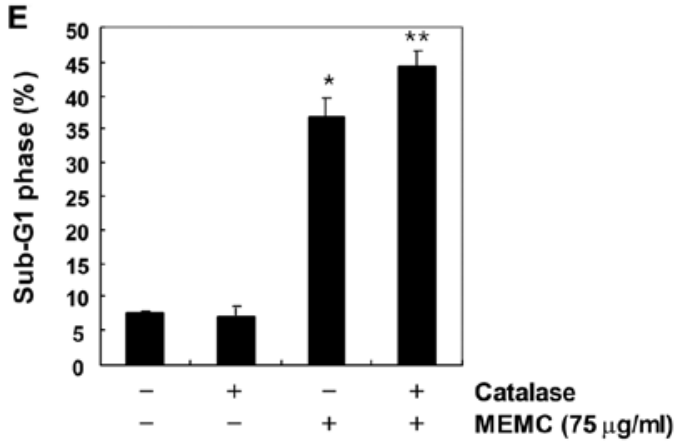

Figure 9. $\mathrm{H}_{2} \mathrm{O}_{2}$ plays an important role in MEMC-induced autophagy and apoptosis in NCI-H460 cells. NCI-H460 cells were seeded in a 6-well plate at an initial density of $2.5 \times 10^{5}$ cells per well. After $24 \mathrm{~h}$ of stabilization, cells were pre-treated with NAC (10 $\left.\mu \mathrm{M}\right)$, SOD (50 U/ml) or catalase ( $\left.2 \times 10^{5} \mathrm{U} / \mathrm{ml}\right)$ for $2 \mathrm{~h}$ and challenged with $75 \mu \mathrm{g} / \mathrm{ml}$ of MEMC for $24 \mathrm{~h}$. (A) Cell viability and (B and E) sub-G1 contents were measured by MTT assay and flow cytometer. (C and D) Cellular proteins were analyzed by western blotting in order to investigate the expression of LC 3 proteins. Actin was used as the internal control. Results are expressed as the means \pm SD of three independent experiments. Statistical significance of the results was analyzed by a Student's t-test $\left({ }^{*} \mathrm{P}<0.05 \mathrm{vs}\right.$. untreated control, ${ }^{* *} \mathrm{P}<0.05$ vs. MEMC-treated cells, not significant vs. MEMC-treated cells).

$\mathrm{H}_{2} \mathrm{O}_{2}$ plays an important role in MEMC-induced autophagy and apoptosis in NCI-H460 cells. Next, in order to investigate the role of ROS in cell death, we blocked ROS generation induced by MEMC using various antioxidants. In the process, NAC, an unspecific ROS scavenger, and superoxide dismutase (SOD), a superoxide-specific scavenger, were used. As indicated in Fig. 9A and B, $1 \mathrm{~h}$ pre-treatment with NAC before MEMC treatment resulted in significantly reduced cell viability and enhancement of the sub-G1 population, while SOD had no noticeable effects. Consistently, these data demonstrate that ROS, except for superoxide, can suppress apoptotic cell death.

Our results showed that ROS also triggered autophagy and that the MEMC-induced autophagy played a protective role against apoptotic cell death in NCI-H460 cells. Therefore, we then attempted to determine whether reduced cell viability by pre-treatment with NAC is associated with autophagy. As shown in Fig. 9C, NAC induced almost the complete blockade of MEMC-induced LC3II upregulation while pre-treatment with SOD did not result in any change in LC3II levels. These results indicate that ROS regulates MEMC-induced autophagy in NCI-H460 cells. Thus, reduced cell viability by NAC treatment might be the result of suppressed autophagy.

As NAC is an unspecific ROS scavenger, we then conducted research to determine which type of ROS is important in the induction of autophagy, using catalase, a hydrogen peroxide specific scavenger. Catalase converts hydrogen peroxide $\left(\mathrm{H}_{2} \mathrm{O}_{2}\right)$ into water $\left(\mathrm{H}_{2} \mathrm{O}\right)$ and oxygen gas $\left(\mathrm{O}_{2}\right)$. As shown in Fig. 9D, scavenging $\mathrm{H}_{2} \mathrm{O}_{2}$ inhibited autophagy, supported by the reduced LC3II level, and increased apoptotic cell death at the same time (Fig. 9E). Similar results were observed with the earlier NAC pre-treatment. Taken together, these data suggest that $\mathrm{H}_{2} \mathrm{O}_{2}$ plays an important role in MEMC-induced autophagy and reconfirms the role of autophagy as a protective mechanism against apoptotic cell death in NCI-H460 cells.

\section{Discussion}

The purpose of this study was to research the anti-tumor effects of MEMC and to determine the related mechanisms. In the process, we used methylene chloride extracts of MEMC and investigated its ability to induce both apoptosis and autophagy in the NCI-H460 NSCLC cell line. Our results showed that MEMC treatment resulted in reduced cell viability in a concentration-dependent manner, which was caused by apoptosis. The MEMC-induced apoptosis was shown by the increase in the sub-G1 population and Annexin V/PI double-stained cells, as well as chromatin condensation and apoptotic body formation. MEMC treatment resulted in the upregulated expression of DR4, DR5 and FasL, crucial members of the extrinsic pathway, leading to the activation of caspase-8 (36). Activated caspase-8 then induced the cleavage of pro-apoptotic Bid, which connects the extrinsic pathway to the intrinsic pathway (5,37). MEMC also affected the intrinsic pathway through the downregulation of anti-apoptotic Bcl-2 and Bcl-xL, and IAP family proteins. Our results also showed that the content of translocated Bax in the mitochondria was increased, even though its total levels 


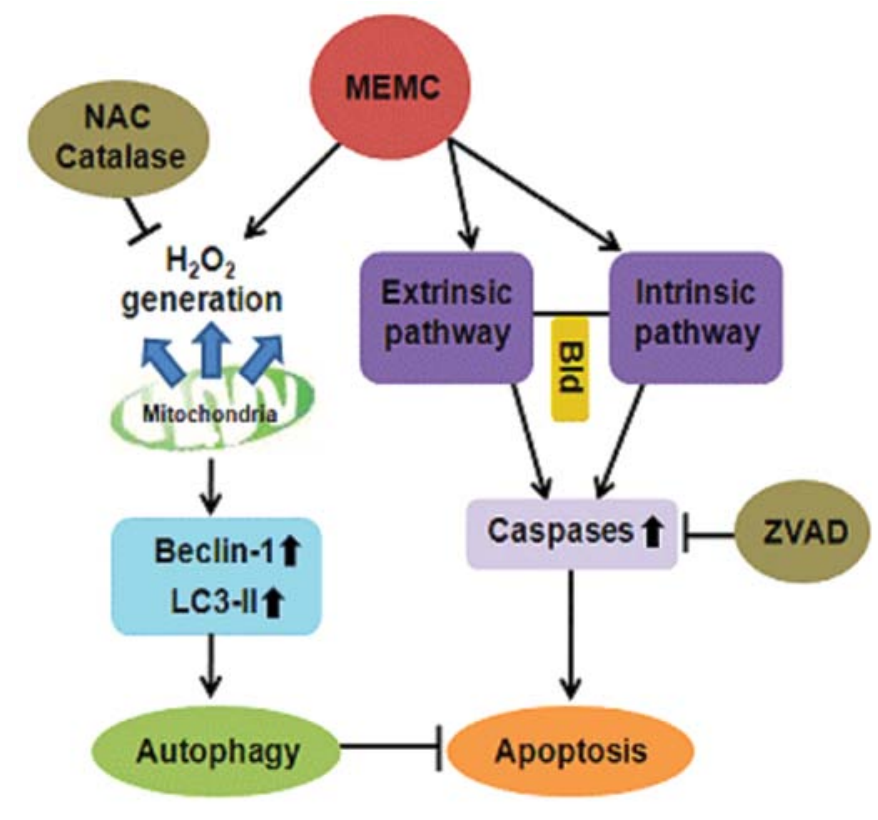

Figure 10. Proposed mechanism of MEMC-induced cell death. MEMC triggers apoptosis via both extrinsic and intrinsic pathways. MEMC-induced apoptosis was blocked by z-VAD-fmk, indicating that activation of caspases is critical for induction of apoptosis by MEMC in NCI-H460 cells. MEMC also generated $\mathrm{H}_{2} \mathrm{O}_{2}$ by causing damage to mitochondria, resulting in autophagy through upregulation of beclin-1 and LC3II. MEMC-induced autophagy functioned as a suppressor of apoptosis, contributing to cell survival. However, once cells are treated with NAC or catalase, MEMC fails to cause $\mathrm{H}_{2} \mathrm{O}_{2}$ accumulation, which is an important factor in induction of autophagy in NCI-H460 cells. As autophagy can no longer function as a survival mechanism, apoptotic cell death is increased. These results imply that regulation of ROS and autophagy could be an important target in treatment of NSCLC.

were slightly decreased. The translocated Bax might have triggered the loss of MMP and release of cytochrome $c$, which finally resulted in the activation of caspase- 9 and -3 . Moreover, pre-treatment with caspase inhibitors resulted in significant suppression of MEMC-induced apoptosis, showing the critical role of caspases in MEMC-induced apoptosis. These results indicate that MEMC treatment causes caspase-dependant apoptosis through the regulation of both extrinsic and intrinsic pathways in NCI-H460 cells.

We also observed the formation of small vacuoles after MEMC treatment. Through earlier studies describing vacuoles similar to those observed in the autophagic process (38), as well as increased MDC-positive cells and upregulated beclin-1 and LC3II, we concluded that MEMC also induced autophagy in NCI-H460 cells. Whether autophagy contributes to cell death or cell survival is still a matter of debate. Autophagy is commonly regarded as a safeguard mechanism that restricts uncontrolled cell growth and eliminates long-lived cytoplasmic organelles. Consistently, the presence of autophagosomes in dying cells might be a protective mechanism for maintenance of cell survival under stress conditions. For example, Lemasters et al (39) reported that a depolarized mitochondria, a feature of apoptosis, was rapidly eliminated by autophagy, which inhibited apoptotic cell death by preventing the release of pro-apoptotic substances from the mitochondria.
However, interest in autophagic cell death is constantly increasing. According to a certain report, autophagy may also contribute to cell death by excessive activation of a self-degrading system (10). Certain reports have even suggested that autophagy might play different roles in different stages of apoptosis (40). Our results demonstrate that MEMC-induced autophagy played a protective role against apoptotic cell death in NCI-H460 cells. We came to that conclusion through the observance of an enhanced sub-G1 population and reduced cell viability after treatment with LC3B siRNA or 3MA, an autophagy inhibitor. In addition, MEMC-induced small vesicles disappeared after treatment with LC3B siRNA, demonstrating that vacuoles were autophagosomes.

To date, data on the interplay between apoptosis and autophagy in response to various death stimuli have continued to accumulate (11-15). It has been suggested that certain signals that are involved in apoptosis may also be included in autophagy. For example, beclin-1, an important protein in the formation of autophagosomes, is known to promote apoptosis through interaction with Bcl-2 (20). Vandenabeele et al (41) reported that z-VAD-fmk treatment blocks apoptotic cell death, sensitizing cells to autophagic cell death. Current evidence has also demonstrated that removal of proteins that are critical for apoptosis can change the form of cell death from apoptosis to autophagic cell death $(42,43)$. Our data indicate that autophagy in cells undergoing apoptosis after MEMC treatment is cytoprotective.

Among the various factors that regulate both apoptosis and autophagy, ROS are a representative regulator. Accumulating research has demonstrated that ROS induce apoptosis via the intrinsic pathway by causing damage to the mitochondria $(44,45)$. However, other studies have suggested that ROS also function as a survival mechanism against cell death through the induction of autophagy and removal of ROS-damaged mitochondria $(41,46)$. As we observed that MEMC induced both apoptosis and autophagy, as well as the loss of MMP, which is the common factor of both phenomenon, we investigated whether ROS generation is associated with these results. Our data showed that MEMC treatment resulted in significantly increased ROS generation in NCI-H460 cells. Of particular interest, during the investigation of the role of MEMC-triggered ROS, we found that NAC, an unspecific antioxidant, induced an increase in apoptotic cell death. In general, most studies have reported on the protective role of NAC against cell death as NAC blocks the mechanism of apoptosis by ROS-damaged cells through the mitochondrialmediated pathway $(47,48)$. If ROS acted only on induction of apoptosis in MEMC-treated cells, NAC must have functioned as a suppressor of apoptosis. Thus, we hypothesized that NAC might have affected autophagy. As shown in our results, NAC induced a marked blockade of LC3 expression, while SOD had no effect on either apoptosis or LC3 levels. In addition, treatment with catalase, the other ROS scavenger blocking $\mathrm{H}_{2} \mathrm{O}_{2}$ specifically, also increased the sub-G1 population and inhibited LC3 expression, which was the same pattern observed after NAC treatment. These data demonstrate the possibility that $\mathrm{H}_{2} \mathrm{O}_{2}$, but not superoxide, induced autophagy, resulting in the suppression of apoptosis. In addition, these results confirm the role of autophagy as a survival mechanism against cell death in MEMC-treated NCI-H460 cells. Recently, Choi et al 
(49) reported that the basal level of intracellular catalase in NCI-H460 cells is limited, whereas the level of SOD is very high. Our data suggest that the limited level of endogenous catalase in NCI-H460 cells failed to eliminate $\mathrm{H}_{2} \mathrm{O}_{2}$ accumulation effectively, resulting in autophagy after MEMC treatment.

In summary, our results show a novel function of MEMC as an inducer of cell death in NSCLC NCI-H460 cells. We also demonstrate that MEMC-induced autophagy is associated with ROS generation and functions as a protective mechanism against apoptotic cell death (Fig. 10). Although further studies are required for the identification of the active compounds of MEMC, these findings suggest that regulation of ROS and autophagy could be an effective strategy for the treatment of NSCLC and for overcoming chemoresistance against apoptosis.

\section{Acknowledgements}

This study was supported by the Basic Science Research Program through the National Research Foundation of Korea (NRF) funded by the Ministry of Education, Science, and Technology (2009-0093193 and 2010-0001730), Republic of Korea.

\section{References}

1. Navada S, Lai P, Schwartz AG and Kalemkerian GP: Temporal trends in small cell lung cancer: analysis of the national Surveillance, Epidemiology and End-Results (SEER) database. $\mathrm{J}$ Clin Oncol 24: S384, 2006.

2. Molina JR, Yang P, Cassivi SD, Schild SE and Adjei AA: Non-small cell lung cancer: epidemiology, risk factors, treatment, and survivorship. Mayo Clin Proc 83: 584-594, 2008.

3. Bria E, Cuppone F and Cecere FL: Adjuvant chemotherapy for non-small cell lung cancer. J Thorac Oncol 2: S7-S11, 2007.

4. Rigas JR and Kelly K: Current treatment paradigms for locally advanced nonsmall cell lung cancer. J Thorac Oncol 2: S77-S85, 2007.

5. Li H, Zhu H, Xu CJ and Yuan J: Cleavage of BID by caspase- 8 mediates the mitochondrial damage in the Fas pathway of apoptosis. Cell 94: 491-501, 1998.

6. Henshall DC, Bonislawski DP, Skradski SL, Lan JQ, Meller R and Simon RP: Cleavage of bid may amplify caspase-8-induced neuronal death following focally evoked limbic seizures. Neurobiol Dis 8: 568-580, 2001.

7. Liu X, Kim CN, Yang J, Jemmerson R and Wang X: Induction of apoptotic program in cell-free extracts: requirement for dATP and cytochrome $c$. Cell 86: 147-157, 1996.

8. Susin SA, Daugas E, Ravagnan L, Samejima K, Zamzami N, Loeffler M, Costantini P, Ferri KF, Irinopoulou T, Prevost MC Brothers G, Mak TW, Penninger J, Earnshaw WC and Kroemer G: Two distinct pathways leading to nuclear apoptosis. J Exp Med 192: 571-580, 2000

9. Meijer AJ and Codogno P: Regulation and role of autophagy in mammalian cells. Int J Biochem Cell Biol 36: 2445-2462, 2004.

10. Gozuacik D and Kimchi A: Autophagy and cell death. Curr Top Dev Biol 78: 217-245, 2007.

11. Shintani T and Klionsky DJ: Autophagy in health and disease: a double-edged sword. Science 306: 990-995, 2004.

12. Lum JJ, Bauer DE, Kong M, Harris MH, Li C, Lindsten T and Thompson CB: Growth factor regulation of autophagy and cell survival in the absence of apoptosis. Cell 120: 237-248, 2005.

13. Paglin S, Hollister T, Delohery T, Hackett N, McMahill M, Sphicas E, Domingo D and Yahalom J: A novel response of cancer cells to radiation involves autophagy and formation of acidic vesicles. Cancer Res 61: 439-444, 2001.

14. Komata T, Kanzawa T, Nashimoto T, Aoki H, Endo S, Nameta M, Takahashi H, Yamamoto T, Kondo S and Tanaka R: Mild heat shock induces autophagic growth arrest, but not apoptosis in U251-MG and U87-MG human malignant glioma cells. J Neurooncol 68: 101-111, 2004.
15. Crighton D, Wilkinson S, O'Prey J, Syed N, Smith P, Harrison PR, Gasco M, Garrone O, Crook T and Ryan KM: DRAM, a p53-induced modulator of autophagy, is critical for apoptosis. Cell 126: 121-134, 2006

16. Kim BM, Choi YJ, Han Y, Yun YS and Hong SH: N,N-dimethyl phytosphingosine induces caspase-8-dependent cytochrome $c$ release and apoptosis through ROS generation in human leukemia cells. Toxicol Appl Pharmacol 239: 87-97, 2009.

17. Yu L, Wan F, Dutta S, Welsh S, Liu Z, Freundt E, Baehrecke EH and Lenardo M: Autophagic programmed cell death by selective catalase degradation. Proc Natl Acad Sci USA 103: 4952-4957, 2006.

18. Scherz-Shouval R and Elazar Z: ROS, mitochondria and the regulation of autophagy. Trends Cell Biol 17: 422-427, 2007.

19. Chen Y, McMillan-Ward E, Kong J, Israels SJ and Gibson SB: Mitochondrial electron-transport-chain inhibitors of complexes I and II induce autophagic cell death mediated by reactive oxygen species. J Cell Sci 120: 4155-4166, 2007.

20. Longo L, Platini F, Scardino A, Alabiso O, Vasapollo G and Tessitore L: Autophagy inhibition enhances anthocyanin-induced apoptosis in hepatocellular carcinoma. Mol Cancer Ther 7: 2476-2485, 2008.

21. Kiffin R, Bandyopadhyay U and Cuervo AM: Oxidative stress and autophagy. Antioxid Redox Signal 8: 152-162, 2006.

22. Chen F, Nakashima N, Kimura I and Kimura M: Hypoglycemic activity and mechanisms of extracts from mulberry leaves (Folium mori) and Cortex mori radicis in streptozotocin-induced diabetic mice. Yakugaku Zasshi 115: 476-482, 1995

23. Nam SY, Yi HK, Lee JC, Kim JC, Song CH, Park JW, Lee DY, Kim JS and Hwang PH: Cortex mori extract induces cancer cell apoptosis through inhibition of microtubule assembly. Arch Pharm Res 25: 191-196, 2002.

24. Chung KO, Kim BY, Lee MH, Kim YR, Chung HY, Park JH and Moon JO: In vitro and in vivo anti-inflammatory effect of oxyresveratrol from Morus alba L. J Pharm Pharmacol 55: 1695-1700, 2003

25. Liu SQ: Clinical application of the theory of the attributive channel of traditional Chinese medicine. Zhong Yao Tong Bao 11: 56-58, 1986.

26. Kim JH, Jang YO, Kim BT, Hwang KJ and Lee JC: Induction of caspase-dependent apoptosis in melanoma cells by the synthetic compound (E)-1-(3,4-dihydroxyphenethyl)-3-styrylurea. BMB Rep 42: 806-811, 2009.

27. Choi JH, Choi AY, Yoon H, Choe W, Yoon KS, Ha J, Yeo EJ and Kang I: Baicalein protects HT22 murine hippocampal neuronal cells against endoplasmic reticulum stress-induced apoptosis through inhibition of reactive oxygen species production and CHOP induction. Exp Mol Med 42: 811-822, 2010.

28. Kim SY, Kang HT, Choi HR and Park SC: Biliverdin reductase A in the prevention of cellular senescence against oxidative stress. Exp Mol Med 43: 15-23, 2011.

29. Ye H, Cande C, Stephanou NC, Jiang S, Gurbuxani S, Larochette N, Daugas E, Garrido C, Kroemer G and Wu H: DNA binding is required for the apoptogenic action of apoptosis inducing factor. Nat Struct Biol 9: 680-684, 2002.

30. Cheung EC, Joza N, Steenaart NA, McClellan KA, Neuspiel M, McNamara S, MacLaurin JG, Rippstein P, Park DS, Shore GC, McBride HM, Penninger JM and Slack RS: Dissociating the dual roles of apoptosis-inducing factor in maintaining mitochondrial structure and apoptosis. EMBO J 25: 4061-4073, 2006.

31. Biederbick A, Kern HF and Elsasser HP: Monodansylcadaverine (MDC) is a specific in vivo marker for autophagic vacuoles. Eur J Cell Biol 66: 3-14, 1995.

32. Aita VM, Liang XH, Murty VV, Pincus DL, Yu W, Cayanis E, Kalachikov S, Gilliam TC and Levine B: Cloning and genomic organization of beclin 1, a candidate tumor suppressor gene on chromosome 17q21. Genomics 59: 59-65, 1999.

33. Kabeya Y, Mizushima N, Ueno T, Yamamoto A, Kirisako T, Noda T, Kominami E, Ohsumi Y and Yoshimori T: LC3, a mammalian homologue of yeast Apg8p, is localized in autophagosome membranes after processing. EMBO J 19: 5720-5728, 2000.

34. Bensaad K, Cheung EC and Vousden KH: Modulation of intracellular ROS levels by TIGAR controls autophagy. EMBO J 28: 3015-3026, 2009.

35. Zorov DB, Filburn CR, Klotz LO, Zweier JL and Sollott SJ: Reactive oxygen species (ROS)-induced ROS release: a new phenomenon accompanying induction of the mitochondrial permeability transition in cardiac myocytes. J Exp Med 192: $1001-1014,2000$ 
36. Kischkel FC, Hellbardt S, Behrmann I, Germer M, Pawlita M Krammer PH and Peter ME: Cytotoxicity-dependent APO-1 (Fas/CD95)-associated proteins form a death-inducing signaling complex (DISC) with the receptor. EMBO J 14: 5579-5588, 1995.

37. Igney FH and Krammer PH: Death and anti-death: tumour resistance to apoptosis. Nat Rev Cancer 2: 277-288, 2002.

38. Pedro M, Lourenco CF, Cidade H, Kijjoa A, Pinto $M$ and Nascimento MS: Effects of natural prenylated flavones in the phenotypical ER (+) MCF-7 and ER (-) MDA-MB-231 human breast cancer cells. Toxicol Lett 164: 24-36, 2006.

39. Lemasters JJ, Nieminen AL, Qian T, Trost LC, Elmore SP, Nishimura Y, Crowe RA, Cascio WE, Bradham CA, Brenner DA and Herman B: The mitochondrial permeability transition in cell death: a common mechanism in necrosis, apoptosis and autophagy. Biochim Biophys Acta 1366: 177-196, 1998.

40. Yang YP, Liang ZQ, Gao B, Jia YL and Qin ZH: Dynamic effects of autophagy on arsenic trioxide-induced death of human leukemia cell line HL60 cells. Acta Pharmacol Sin 29: 123-134, 2008.

41. Vandenabeele P, Vanden Berghe T and Festjens N: Caspase inhibitors promote alternative cell death pathways. Sci STKE 2006: pe44, 2006.

42. Yu L, Alva A, Su H, Dutt P, Freundt E, Welsh S, Baehrecke EH and Lenardo MJ: Regulation of an ATG7-beclin 1 program of autophagic cell death by caspase-8. Science 304: 1500-1502, 2004

43. Levine B and Yuan J: Autophagy in cell death: an innocent convict? J Clin Invest 115: 2679-2688, 2005.
44. Shin DY, Shin HJ, Kim GY, Cheong J, Choi IW, Kim SK, Moon SK, Kang HS and Choi YH: Streptochlorin isolated from Streptomyces $s p$. Induces apoptosis in human hepatocarcinoma cells through a reactive oxygen species-mediated mitochondrial pathway. J Microbiol Biotechnol 18: 1862-1868, 2008.

45. Ganguly A, Basu S, Chakraborty P, Chatterjee S, Sarkar A, Chatterjee $\mathrm{M}$ and Choudhuri SK: Targeting mitochondrial cell death pathway to overcome drug resistance with a newly developed iron chelate. PLoS One 5: e11253, 2010.

46. Li J, Liu R, Lei Y, Wang K, Lau QC, Xie N, Zhou S, Nie C, Chen L, Wei Y and Huang C: Proteomic analysis revealed association of aberrant ROS signaling with suberoylanilide hydroxamic acidinduced autophagy in Jurkat T-leukemia cells. Autophagy 6: 711-724, 2010.

47. Panaretakis T, Shabalina IG, Grandér D, Shoshan MC and DePierre JW: Reactive oxygen species and mitochondria mediate the induction of apoptosis in human hepatoma HepG2 cells by the rodent peroxisome proliferator and hepatocarcinogen, perfluorooctanoic acid. Toxicol Appl Pharmacol 173: 56-64, 2001

48. Kurosu T, Fukuda T, Miki T and Miura O: BCL6 overexpression prevents increase in reactive oxygen species and inhibits apoptosis induced by chemotherapeutic reagents in B-cell lymphoma cells. Oncogene 22: 4459-4468, 2003.

49. Choi CH, Jung YK and Oh SH: Selective induction of catalasemediated autophagy by dihydrocapsaicin in lung cell lines. Free Radic Biol Med 49: 245-257, 2010. 